\title{
Water Pollution Index of Batujai Reservoir, Central Lombok Regency-Indonesia
}

\author{
Abdul Rahim ${ }^{1}$, Tri Retnaningsih Soeprobowati ${ }^{2,3 *}$ \\ 1 Master Program of Environmental Science, School of Postgraduate Studies, Diponegoro University, Indonesia \\ 2 Department of Biology, Faculty of Science and Mathematics Diponegoro University, Indonesia \\ 3 School of Postgraduate Studies, Diponegoro University, Indonesia \\ * Corresponding author's e-mail: trsoeprobowati@live.undip.ac.id
}

\begin{abstract}
Batujai reservoir is located in Central Lombok Regency, Indonesia. The government and local people use it for hydropower generation, drinking water, agricultural irrigation, fish farming, and tourism. The phenomenon of growing population and increasing industrial activities in the catchment area of Batujai reservoir always result in the discharge of various pollutants into the aquatic environment and cause the blooming of water hyacinth over almost $30 \%$ of the reservoir area. The aim of this study was to determine the water pollution index of Batujai reservoir. The samples were analysed for the following parameters: $\mathrm{pH}$, temperature, $\mathrm{DO}, \mathrm{COD}, \mathrm{BOD}$, TSS, and heavy metals. The research was done by using purposive sampling method and determination of water quality status with STORET method based on Government Regulation No. 82/2001. The measurement results show that the physical and chemical parameters of the Batujai reservoir water do not exceed the quality standard are the temperature (29 to $\left.32^{\circ} \mathrm{C}\right) ; \mathrm{pH}(6.6$ to $7.5 \mathrm{mg} / \mathrm{L})$; nitrate $(0.421$ to $0.546 \mathrm{mg} / \mathrm{L}) ; \mathrm{Cd}(0.0005$ to $0.005 \mathrm{mg} / \mathrm{L}) ; \mathrm{Cr}(<0.001$ to $0.018 \mathrm{mg} / \mathrm{L})$; and the parameters that exceed quality standards are DO (3.8 to $4.9 \mathrm{mg} / \mathrm{L})$; BOD (3.03 to $4.21 \mathrm{mg} / \mathrm{L})$; COD (6.8 to $10.1 \mathrm{mg} / \mathrm{L})$; phosphate $(0.181$ to $0.237 \mathrm{mg} / \mathrm{L})$; and $\mathrm{Pb}(0.14$ to $0.24 \mathrm{mg} / \mathrm{L})$. The water quality status of Batujai reservoir was heavily polluted for standard quality on class I, II, III and moderately polluted for class IV.
\end{abstract}

Keywords: STORET, physical-chemical parameter, water quality, pollution index, Batujai reservoir

\section{INTRODUCTION}

Water is a valuable resource and it is highly essential for the survival of mankind. Freshwater ecosystems such as lakes, reservoirs and rivers are natural resources that play an important role in ensuring the water availability on land. The 2030 agenda for Sustainable Development acknowledges the importance of water quality and includes a specific water quality target in Sustainable Development Goals (SDGs) 6 (United Nation, 2016). However, the surface water pollution remains a major problem worldwide, caused by both natural processes and anthropogenic activities (Noori et al., 2010).

In Indonesia, The condition of freshwater is always an issue that threatens its sustainability and becomes a national problem (Soeprobowati et al. 2016). For example, the problem of Rawa Pening Lake in Central Java Province is the occurrence of eutrophication, sedimentation, water quality degradation, and blooming of water hyacinth (Soeprobowati et al. 2017; Hidayati et al. 2018). The same problem also occurs at other lakes of national priority, including Lakes of Toba, Maninjau, Singkarak, Kerinci, Tondano, Limboto, Poso, Tempe, Matano, Cascade Mahakam Semayang-Melintang Jempang, Sentarum, Sentani, Rawa Danau, Batur (MoE, 2010), Telaga Warna Dieng (Soeprobowati et al., 2017) and several reservoirs such as Saguling, Cirata, Jatiluhur, Lahor, Karangkates, and Sengguruh (Chrismadha et al., 2011).

The Batujai reservoir is one of the reservoirs in Lombok Island which was built in 1977-1982 with the water depth variation of $6-8 \mathrm{~m}$ as well 
as 890 -hectare inundation area and 25 million $\mathrm{m}^{3}$ capacity. The government and local people use it for hydropower generation, drinking water, agricultural irrigation, fish farming, and tourism. However, the phenomenon of growing population and increasing industrial activities in the catchment area of Batujai reservoir always result in the discharge of various pollutants into the aquatic environment. The pollutants can come from various sources, such as urbanization, high population growth, disposal of domestic waste, excessive use of pesticides and fertilizers in agriculture are the main sources of water pollution (Haseena et al., 2017).

The main problem every year on the surface water in Batujai reservoir is the blooming of water hyacinth over almost $30 \%$ of the reservoir area (Firdaus, 2011). The rapid growth of water hyacinth is a result of the proliferation of the nutrients in the freshwater (Soeprobowati, 2012). Agriculture has been identified as the largest contributor of nonpoint source pollution to surface water and groundwater worldwide (Chhabra et al., 2010). It corresponds to about 70 percent of water abstractions worldwide and plays a major role in water pollution. Farms discharge large quantities of agrochemicals, organic matter, drug residues, sediments and saline drainage into water bodies. The resultant water pollution poses risks to aquatic ecosystems, human health and productive activities (UNEP, 2016). Therefore, the purpose of this study was to determine the water quality and the pollution index of the Batujai reservoir.

\section{MATERIALS AND METHODS}

This study was conducted in January to February 2018 at Batujai Reservoir, Central Lombok Regency, Indonesia (080 43' 58.21'S 116015 '23.15 "E). Five sampling stations with different characteristic by purposive random sampling, which represented the whole waters of the Batujai Reservoir, were established. Determination of the sampling station location was conducted at the edge of the reservoir and based on the waste stream from community activities (Fig. 1).

The water samples were taken at each sampling station in accordance with the Indonesian National Standard (SNI 6989.57-2008) concerning the Method of Taking Surface Water Samples that the depth of the reservoir is less than 10 meters. The sampling of water was carried out on 2 (two) points, involving the surface and the bottom, mixed afterwards (composite depth). The water samples were collected into clean plastic bottles with labels and placed into a coolbox. The physicochemical parameters such as temperature, $\mathrm{pH}$ and dissolved oxygen (DO) were measured directly in the field, while others were analysed in the Analytical Chemistry Laboratory of Mathematics and Natural Sciences Faculty, Mataram University.

The values of physical and chemical parameters of water are compared with the criteria of water quality standards in Government Regulation No. 82/2001 concerning Management of Water Quality and Water Pollution Control. Determination of the water quality status in the Batujai

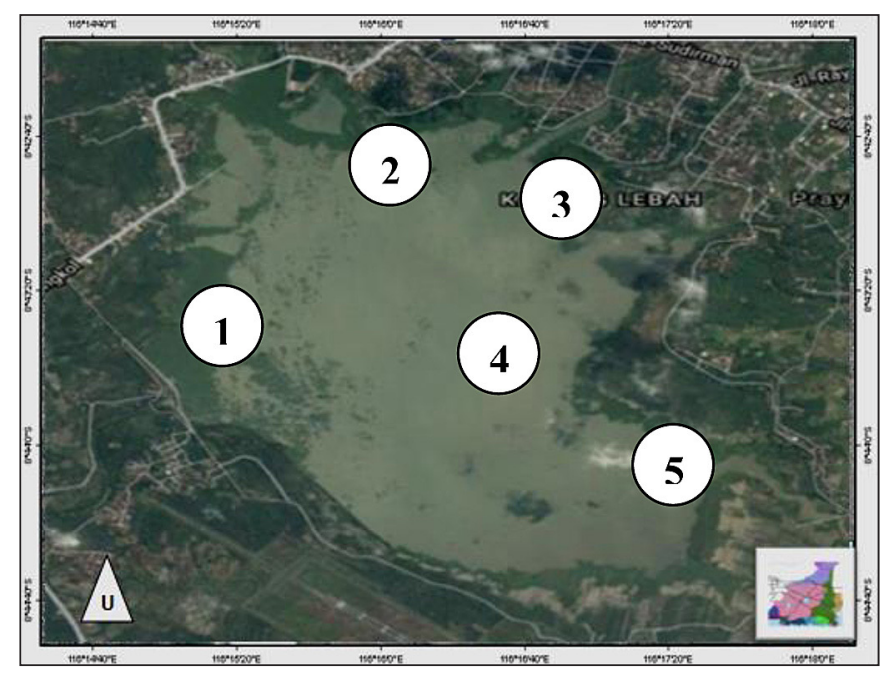

Figure 1. Area of sampling stations in Batujai reservoir; station $1:$ area of the fish cultivation ( $8^{\circ} 43^{\prime} 20.4^{\prime \prime} \mathrm{S}$

$\left.116^{\circ} 15^{\prime} 40.3^{\prime \prime} \mathrm{E}\right)$; station 2: area of the urban/settlement ( $\left.8^{\circ} 43^{\prime} 06.2^{\prime \prime} \mathrm{S} 116^{\circ} 16^{\prime} 05.9^{\prime} \mathrm{E}\right)$; station 3: inlet area

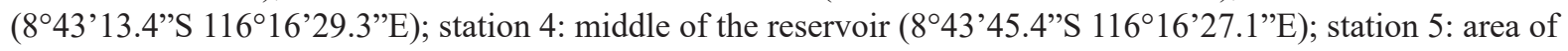
the agriculture $\left(8^{\circ} 44^{\prime} 14.4^{\prime \prime} \mathrm{S} 116^{\circ} 16^{\prime} 28.8^{\prime \prime} \mathrm{E}\right)$ 
reservoir by using the STORET Method (Storage and Retrieval) which refers to Ministry of Environment of Indonesia No. 115/2003 [15] concerning Guidelines for Determining the Status of Water Quality. In Indonesia, the STORET method is one of the popular techniques of determiming water quality status based on the value system from US-EPA (United State-Environmental Protection Agency) to categorize the water quality into four classes (http://www.epa.gov/storet/) (Table 1).

Determination of the water quality status using the STORET method is done with the following steps:

1. Performing periodic water quality data collection to form data from time to time (Time series)

2. Comparing the measurement data from each water parameter with the value of quality standard in accordance with the water class.

3 . If the measurement results meet the water quality standard (Measurement results < quality standard) then a score of 0 is given.

4. If the results of the measurement do not meet the water quality standard (Measurement Results $>$ quality standard), then a score like in Table 2 is given:

5. The negative number of all parameters is calculated and the quality status of the total score obtained by using the value system is detemined.

\section{RESULTS AND DISCUSSION}

\section{Analysis of physicochemical parameters}

The collection and measurement of water samples were carried out from 10 to 11 a.m. at each sampling station in the Batujai reservoir. The measurement results of the water quality based on the physicochemical parameters can be seen in Table 3 .

\section{Temperature}

The water temperature at all stations ranged from 29 to $32^{\circ} \mathrm{C}$ (Table 3) with an average value was $30.4^{\circ} \mathrm{C}$. The highest temperature reaches $32^{\circ} \mathrm{C}$ at station 5 (around of the agricultural area). The average value of the water temperature is still in accordance with the water quality standard criteria of Government Regulation No. 82/2001 for class I, II, III, and IV which requires the temperature of the water to be at a deviation of $3^{\circ} \mathrm{C}$ from the natural conditions of the surrounding environment.

\section{Total suspended solids}

The measurement results of Total Suspended Solids (TSS) at all sampling stations in the Batujai reservoir showed that the TSS values ranged from 58 to $104 \mathrm{mg} / \mathrm{L}$ (Table 3) with an average value was $81.4 \mathrm{mg} / \mathrm{L}$. The parameters of TSS exceeded the class I and II water quality standards that were determined by Government Regulation No. 82 of 2001, reaching $50 \mathrm{mg} / \mathrm{L}$ and were below the class III and IV quality standards. The TSS value at station 3 is an inlet area which tends to be higher when compared to other stations which indicate that the inlet area many carry erosion from upstream areas.

\section{The degree of acidity $(\mathrm{pH})$}

The measurement results of the $\mathrm{pH}$ obtained at sampling station 1 to 5 in the Batujai reservoir ranged from 6.6 to 7.5 (Table 3 ) with an average value of 7.19. The $\mathrm{pH}$ value was still within the threshold of water quality standard for Class I, II, III, and IV from Government Regulation No. $82 / 2001$ which requires a $\mathrm{pH}$ range from 6-9. The degree of acidity $(\mathrm{pH})$ of water shows the presence of hydrogen ions in water because hydrogen ions are acidic.

\section{Dissolved oxygen}

The measurement results of dissolved oxygen (DO) water obtained at all of the sampling stations in the Batujai reservoir ranged from 3.8 to $4.9 \mathrm{mg} / \mathrm{L}$ (Table 3 ) with an average value of 4.4 $\mathrm{mg} / \mathrm{L}$. The DO value was below the class I quality standard according to Government Regulation No. $82 / 2001$ which requires DO is $6 \mathrm{mg} / \mathrm{L}$. However, it exceeded the water quality standards for the class II and III. Le et al. (2010) reported that if organic wastes in water were high, the dissolved oxygen content would be low.

Table 1. Classification of Water quality from the USEPA value system

\begin{tabular}{|c|c|l|}
\hline Score & Class & Characteristics of Water Quality \\
\hline 0 & A & meet the quality standard \\
\hline-1 to -10 & B & lightly polluted \\
\hline-11 to -30 & C & moderately polluted \\
\hline$\geq-31$ & D & highly polluted \\
\hline
\end{tabular}


Table 2. Parameter scoring of water quality (MoE No. 115/2003)

\begin{tabular}{|c|l|c|c|c|}
\hline \multirow{2}{*}{ Number of Samples } & \multicolumn{2}{|c|}{ Value } & \multicolumn{3}{|c|}{ Parameters } \\
\cline { 3 - 5 } & & Physics & Chemistry & -3 \\
& & -1 & -2 & -3 \\
\hline \multirow{3}{*}{$<10$} & Maximum & -1 & -2 & -9 \\
& Minimum & -3 & -6 & -6 \\
& Average & -2 & -4 & -6 \\
\hline \multirow{3}{*}{$\geq 10$} & Maximum & -2 & -4 & -18 \\
\hline & Minimum & -6 & -12 & \\
& Average & &
\end{tabular}

\section{Biological Oxygen Demand}

The measurement results of Biological Oxygen Demand (BOD) water obtained at all of the sampling stations in the Batujai reservoir ranged from 3.03 to $4.21 \mathrm{mg} / \mathrm{L}$ (Table 3) with an average value of $3.8 \mathrm{mg} / \mathrm{L}$. The BOD value exceeded the class I and II quality standards according to Government Regulation No. 82/2001 with the permissible limit of BOD value is 2 and $3 \mathrm{mg} / \mathrm{L}$ respectively. However, it is still below the water quality standard threshold for classes III and IV, which are 6 and $12 \mathrm{mg} / \mathrm{L}$, respectively.

\section{Chemical Oxygen Demand}

Chemical Oxygen Demand (COD) describes the need for oxygen to decompose organic matter chemically and results in reduced oxygen dissolved in the water. The measurement results of COD obtained at all of the sampling stations in Batujai reservoir ranged from 6.8 to $10.1 \mathrm{mg} / \mathrm{L}$ (Table 3) with an average value of $8.3 \mathrm{mg} / \mathrm{L}$. The average value of COD was still within the threshold of quality standards for Class I, II, III, and IV recommended by Government Regulation No. 82/2001.

\section{Nitrate}

The measurement results of nitrate at all sampling stations in the Batujai reservoir showed that the concentration of nitrate $\left(\mathrm{NO}_{3}-\right.$ $\mathrm{N}$ ) ranged from 0.421 to $0.546 \mathrm{mg} / \mathrm{L}$ (Table 3) with an average value was $0.5 \mathrm{mg} / \mathrm{L}$. The nitrate concentration was still low even though it was not in the natural condition $(>0.1 \mathrm{mg} / \mathrm{L})$. The average value of nitrate was still within the threshold of quality standards for Class I, II, III, and IV recommended by Government Regulation No. 82/2001.

\section{Phosphate}

The measurement results of the phosphate $\left(\mathrm{PO}_{4}-\mathrm{P}\right)$ concentration at 5 sampling stations in the Batujai reservoir ranged from 0.181 to 0.237 $\mathrm{mg} / \mathrm{L}$ (Table 3) with an average value of 0.19 $\mathrm{mg} / \mathrm{L}$. The phosphate value still meets the water quality criteria for the class I, II, III, and IV. However, the tropical status criteria for lakes/ reservoirs according to the Minister of Environment Regulation No. 28/2009 was at the average level of total $\mathrm{P}<100 \mu \mathrm{g} / \mathrm{L}$. Therefore, based

Table 3. Physicochemical parameters of the Batujai reservoir

\begin{tabular}{|c|c|c|c|c|c|c|c|c|c|c|}
\hline \multirow{2}{*}{ Parameters } & \multirow{2}{*}{ Unit } & \multicolumn{5}{|c|}{ Sampling Stations } & \multicolumn{4}{|c|}{$\begin{array}{l}\text { Standard of Government Regulation No. } \\
82 / 2001\end{array}$} \\
\hline & & S1 & $\mathrm{S} 2$ & S3 & S4 & S5 & Class I & Class II & Class III & Class IV \\
\hline \multicolumn{11}{|l|}{ Physics } \\
\hline Temperature & ${ }^{\circ} \mathrm{C}$ & 29 & 31 & 30 & 30 & 32 & Dev3 & Dev3 & Dev3 & Dev3 \\
\hline TSS & $\mathrm{mg} / \mathrm{L}$ & 77 & 74 & 104 & 58 & 94 & 50 & 50 & 400 & 400 \\
\hline \multicolumn{11}{|l|}{ Chemical } \\
\hline $\mathrm{pH}$ & - & 7.21 & 7.23 & 7.32 & 6.64 & 7.53 & $6-9$ & $6-9$ & $6-9$ & $5-9$ \\
\hline $\mathrm{DO}$ & $\mathrm{mg} / \mathrm{L}$ & 4.5 & 4.62 & 4.9 & 3.8 & 4.1 & 6 & 4 & 3 & 0 \\
\hline BOD & $\mathrm{mg} / \mathrm{L}$ & 3.84 & 3.94 & 4.21 & 3.03 & 4.06 & 2 & 3 & 6 & 12 \\
\hline COD & $\mathrm{mg} / \mathrm{L}$ & 7.90 & 7.84 & 10.06 & 6.82 & 8.85 & 10 & 25 & 50 & 100 \\
\hline Nitrat & $\mathrm{mg} / \mathrm{L}$ & 0.54 & 0.507 & 0.546 & 0.42 & 0.508 & 10 & 10 & 20 & 20 \\
\hline Fosfat & $\mathrm{mg} / \mathrm{L}$ & 0.18 & 0.197 & 0.183 & 0.195 & 0.237 & 0.2 & 0.2 & 1 & 5 \\
\hline $\mathrm{Cd}$ & $\mathrm{mg} / \mathrm{L}$ & 0.005 & 0.002 & 0.0005 & 0.0005 & 0.002 & 0.01 & 0.01 & 0.01 & 0.01 \\
\hline $\mathrm{Cr}$ & $\mathrm{mg} / \mathrm{L}$ & 0.01 & $<0.01$ & $<0.01$ & $<0.001$ & 0.018 & 0.05 & 0.05 & 0.05 & 1 \\
\hline $\mathrm{Pb}$ & $\mathrm{mg} / \mathrm{L}$ & 0.14 & 0.17 & 0.24 & 0.17 & 0.16 & 0.03 & 0.03 & 0.03 & 1 \\
\hline
\end{tabular}


on the phosphate concentration in the waters of the Batujai reservoir, it is classified as eutrophic water. Sulawesty et al. (2013) reported that the Batujai reservoir in Central Lombok Regency was classified as eutrophic waters based on the content of nitrogenic, phosphorus, and chlorophyll-a compounds.

Phosphates are not toxic to people or animal unless they are present in water at high levels. The digestive problem could occur due to the extremely high level of phosphate (WHO, 2011). The high concentration of phosphorus in the waters is an indication of the contamination of organic matter from agricultural, livestock or fisheries and household waste containing phosphorus which enters the reservoir (Casali et al. 2010).

\section{Concentration of heavy metals}

The analysis results of several heavy metals in the water samples obtained at all sampling stations in the Batujai reservoir were as follows: the $\mathrm{Cd}$ concentration ranged from 0.0005 to $0.005 \mathrm{mg} / \mathrm{L}$; $\mathrm{Cr}$ concentration ranged from $<0.001$ to $0.018 \mathrm{mg} / \mathrm{L}$; and $\mathrm{Pb}$ metal had the highest concentration among other heavy metals, which ranged from 0.14 to $0.24 \mathrm{mg} / \mathrm{L}$ (Table 3 ) with an average value was $0.18 \mathrm{mg} / \mathrm{L}$. The concentration of $\mathrm{Pb}$ exceeded the quality standards of class I, II, and III that were recommended by Government Regulation No. $82 / 2001$ and amounted to $0.03 \mathrm{mg} / \mathrm{L}$, while the concentration of $\mathrm{Cr}$ and $\mathrm{Cd}$ were still below the quality standard for all classes.

\section{Determination of water quality status}

Determination of the overall pollutant level can be analyzed using the STORET method. The STORET method can describe the parameters that fulfill or exceed the water quality standard. The basic concept of the STORET index involves comparing each of the water quality data to its standard and then scoring. The scoring value is based on US-EPA (United State-Environmental Protection Agency) system. On the basis of the calculation using the STORET method, the acquired water quality status of Batujai reservoir can be seen in Table 4 .

Table 4 shows the water quality status of the Batujai reservoir using the STORET method with the classification of water quality status from Government Regulation No. 82/2001 which can be described as follows; Class I used as a source of drinking water has a pollution index of -58 , Class II used for recreation, livestock and fish farming has a pollution index of -70 , Class III used for livestock, fish farming and agriculture has a pollution index of -40 , and Class IV used for agriculture has a pollution index of -20 . Based on the water pollution index of STORET, the water quality status of Batujay Reservoir was heavily polluted for standard quality class I, II, and III, and moderately polluted for class IV.

Table 4. Water quality status of the Batujai reservoir using the STORET method

\begin{tabular}{|c|c|c|c|c|c|c|c|c|c|c|c|c|}
\hline \multirow{2}{*}{ Parameters } & \multicolumn{5}{|c|}{ Sampling Stations } & \multirow{2}{*}{ Max. } & \multirow{2}{*}{ Min. } & \multirow{2}{*}{ Avge. } & \multirow{2}{*}{$\begin{array}{l}\text { Score } \\
\text { Class I }\end{array}$} & \multirow{2}{*}{$\begin{array}{l}\text { Score } \\
\text { Class II }\end{array}$} & \multirow{2}{*}{$\begin{array}{l}\text { Score } \\
\text { Class III }\end{array}$} & \multirow{2}{*}{$\begin{array}{l}\text { Score } \\
\text { Class IV }\end{array}$} \\
\hline & S1 & S2 & S3 & S4 & S5 & & & & & & & \\
\hline \multicolumn{13}{|l|}{ Physics } \\
\hline Temperature & 29 & 31 & 30 & 30 & 32 & 32 & 29 & 30,4 & 0 & 0 & 0 & 0 \\
\hline TSS & 77 & 74 & 104 & 58 & 94 & 104 & 58 & 81,4 & -10 & -10 & 0 & 0 \\
\hline \multicolumn{13}{|l|}{ Chemical } \\
\hline $\mathrm{pH}$ & 7,21 & 7,23 & 7,32 & 6,64 & 7,53 & 7,53 & 6,64 & 7,19 & 0 & 0 & 0 & 0 \\
\hline DO & 4,5 & 4,62 & 4,9 & 3,8 & 4,1 & 4,9 & 3,8 & 4,4 & 0 & -16 & -20 & -20 \\
\hline BOD & 3,84 & 3,94 & 4,21 & 3,03 & 4,06 & 4,21 & 3,03 & 3,82 & -20 & -20 & 0 & 0 \\
\hline COD & 7,90 & 7,84 & 10,06 & 6,82 & 8,85 & 10,06 & 6,82 & 8,3 & -4 & 0 & 0 & 0 \\
\hline Nitrat & 0,54 & 0,51 & 0,546 & 0,42 & 0,51 & 0,55 & 0,42 & 0,5 & 0 & 0 & 0 & 0 \\
\hline Fosfat & 0,181 & 0,197 & 0,183 & 0,195 & 0,237 & 0,24 & 0,18 & 0,2 & -4 & -4 & 0 & 0 \\
\hline $\mathrm{Cd}$ & 0,005 & 0,002 & 0,0005 & 0,0005 & 0,002 & 0,005 & 0,0005 & 0,002 & 0 & 0 & 0 & 0 \\
\hline $\mathrm{Cr}$ & 0,01 & $<0,01$ & $<0,01$ & $<0,001$ & 0,018 & 0,018 & $<0,001$ & 0,014 & 0 & 0 & 0 & 0 \\
\hline $\mathrm{Pb}$ & 0,14 & 0,17 & 0,24 & 0,17 & 0,16 & 0,24 & 0,14 & 0,17 & -20 & -20 & -20 & 0 \\
\hline \multicolumn{2}{|c|}{ Pollution Index } & & & & & & & & -58 & -70 & -40 & -20 \\
\hline \multicolumn{3}{|c|}{ Number of Sample $11 \geq 10$ ) } & & & & & & & & & & \\
\hline
\end{tabular}


A similar research by Sugiyarto et al. (2010), concerning the water quality status at Sampean Watershed Bondowoso Residence shows that the first, second, third and fourth grade are -24 (moderate quality), -12 (moderate quality), -2 (good quality), and 0 (good quality), respectively.

Central Lombok Regency has an area of $1,208.39 \mathrm{~km}^{2}$ with a catchment of the Batujai Reservoir covering an area of $168 \mathrm{~km}^{2}$ which is located upstream, consists of: Praya City, Central Praya District, Janapria District, Kopang District, Jonggat District, Batukliang District and West Praya District. In 2016, the total population of Central Lombok Regency was 922.088 people, while the population occupying seven sub-districts in the Batujai Reservoir was 576,506 people (Statistics of Central Lombok Regency, 2017). The source of pollution at the Batujai reservoir comes from domestic waste, industrial waste, agricultural waste and livestock waste (Firdaus, 2011). Simon et al. (2010) reported that the water quality of the Batujai reservoir in the rain season and dry season still meets the standards for raw water sources (class 1) except for BOD and COD parameters.

\section{CONCLUSIONS}

The measurement results show that the physical and chemical parameters of the Batujai reservoir water that do not exceed the quality standard include the temperature, $\mathrm{pH}$, nitrate, $\mathrm{Cd}, \mathrm{Cr}$, whereas the parameters that exceed the quality standards are DO, BOD, COD, phosphate, and $\mathrm{Pb}$. The water quality status of the Batujai reservoir was heavily polluted for standard quality on class I, II, III and moderately polluted for class IV.

\section{Acknowledgements}

The author wishes to thank Mr. H. Idris as head of the Analytical Chemistry Laboratory of Mathematics and Natural Sciences Faculty, Mataram University-Indonesia for his guidance and help in lab work. The heartfelt thanks to Ahmad Fadlullah and M. Sidiq for their help in the field work.

\section{REFERENCES}

1. Casali J.R., Gimenez J., Diez J., Álvarez-Mozos J.D.V., de Lersundi M., Goni M.A., Campo Y., Chahor R.,. Gastesi J., Lopez. 2010. Sediment production and water quality of watersheds with contrasting land use in Navarre (Spain). Agricultural Water Management, 97, 1683-1694.

2. Central Bureau of Statistics Central Lombok Regency, 2017. Central Lombok Regency in 2017. Maharani.

3. Chhabra A., Manjunath K.R., Panigrahy S. 2010. Non-point source pollution in Indian agriculture: estimation of nitrogen losses from rice crop using remote sensing and GIS. International Journal of Applied Earth Observation and Geoinformation, 12, 190-200.

4. Chrismadha T. et al. 2011. Ecohydrological application in lake management. In: National Symposium on Ecohydrology. Jakarta, 23-42.

5. Firdaus A. 2011. Impact of environmental pollution of Praya City to water quality in Batujai Reservoir. Bulletin of Environmental Geology, 21(2), 69-82 (in Indonesian).

6. Haseena M., Malik M.F., Javed A., Arshad S., Asif N., Zulfiqar S., Hanif J. 2017. Water pollution and human health. Environ Risk Assess Remediat, 1(3).

7. Hidayati N., Soeprobowati T.R., Helmi M. 2018. The evaluation of water hyacinth (Eichhornia crassipes) control program in Rawapening Lake, Central Java Indonesia. IOP Conf. Series: Earth and Environmental Science, 142, 012-016.

8. Indonesian Government Regulation, 2001. Regarding the water quality management and water pollution control, No. 82, Jakarta.

9. Le C. et al. 2010. Eutrophication of lake waters In China: Cost, Causes, and Control. Environmental Management, 45(4).

10. Ministry of Environment of Indonesia, 2003. The guidance of water quality status in Indonesia. Decree, No. 115, Jakarta.

11. Ministry of Environment of Indonesia, 2010. 2010-2014 National lake priority program. Jakarta [in Indonesian].

12. Noori R., Sabahi M.S., Karbassi A.R., Baghvand A., Taati Zadeh H. 2010. Multivariate statistical analysis of surface water quality based on correlations and variations in the data set. Desalination, 260, 129-136.

13. Simon S.B., Firdaus A., Yani S., 2010. Nutrient pollution (hara substance) and water reservoir quality Batujai Kaskade and Pengga in Lombok Island. Journal Sumber Daya Air, 6(1), 1-100.

14. Soeprobowati T.R., Tandjung S. D., Sutikno, Hadisusanto S., Gell P., Hadiyanto, Suedy S.W.A. 2016. The water quality parameters controlling diatoms assemblage in Rawapening Lake, Indonesia. Biodiversitas, 17(2), 657-664.

15. Soeprobowati T.R. 2017. Lake Management: Lesson Learn from Rawa Pening Lake. American 
Scientific Publishers, 23(7), 6495-6497.

16. Soeprobowati T.R., Suedy S.W.A., Hadiyanto. 2017. Diatoms and water quality of Telaga Warna Dieng, Java Indonesia. IOP Conf. Series: Earth and Environmental Science 55 012051, doi:10.1088/1755-1315/55/1/012051.

17. Soeprobowati T.R. 2012. Mitigasi danau eutrofik: studi kasus Danau Rawapening. Prosiding Seminar Nasional Limnologi VI. Bogor: LIPI, pp. 36-48.

18. Sugiayarto, Hariono B., Destarianto P., Nurudin M. 2017. Determination of water quality status at Sampean Watershed Bondowoso Residence using storet method. IOP Conf. Series: Journal of Physics: Conf. Series 953(2018) 012126, doi :10.1088/1742-6596/953/1/012126.
19. Sulawesty et al. 2013. Limnologic character of freshwater in Central Lombok, West Nusa Tenggara. LIPI Research Center. Limnotek 20 (2), 117-128 [In Indonesian].

20. UNEP 2016. A snapshot of the world's water quality: Towards a global assessment. Nairobi, United Nations Environment Programme (UNEP).

21. United Nations 2016. Report of the Inter-agency and expert group on Sustainable Development Goals Indicators. 47th Session of the United Nations Statistical Commission. New York, USA.

22. WHO 2011. The degree of hardness drinking water is important for aesthetic acceptability by consumers and for economic and Operational consideration. 